\title{
Sickle Cell Trait
}

National Cancer Institute

\section{Source}

National Cancer Institute. Sickle Cell Trait. NCI Thesaurus. Code C39800.

An individual who is heterozygous for the mutation that causes sickle cell anemia. 